\title{
Invasion, Infection, Invisibility: An Iconology of Illegalized Immigration
}

FRANCESCA FALK

What is perceived as familiar or unfamiliar, as being part of the community or not, is very often the result of mental and material images: Communities are imagined and thus constituted among others by certain kinds of visualizations.

Figure 1

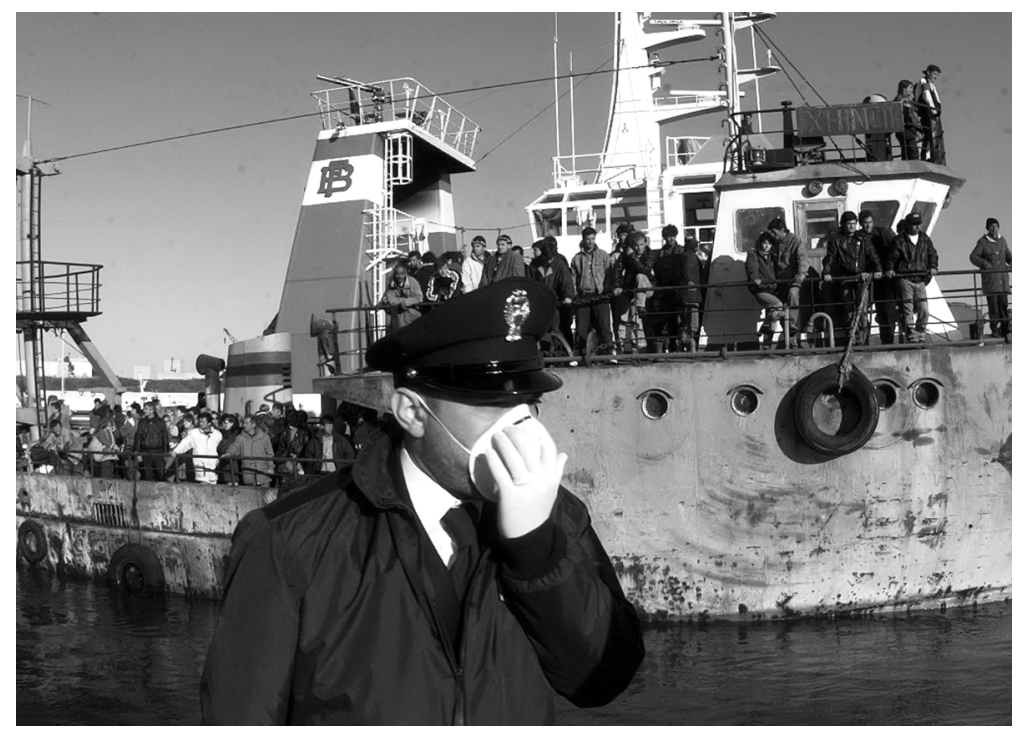


"A carabiniere with a mask, seen today in the harbour of Brindisi at the arrival of a fishing cutter filled with illegal immigrants from Albania"1, says the caption of a photograph from Associated Press. With a white seethrough glove, the elegant officer presses a mask to his mouth. He turns his back on the crowded ship where the illegalized immigrants are waiting. We see many men, some women and a few children, all standing and looking at us. In 1997 Albania was ravaged by riots and as a consequence many Albanian refugees ${ }^{2}$ arrived in Italy. This was reminiscent of the situation in 1991, when Albania's former communist regime collapsed and mass emigration began.

Figure 2

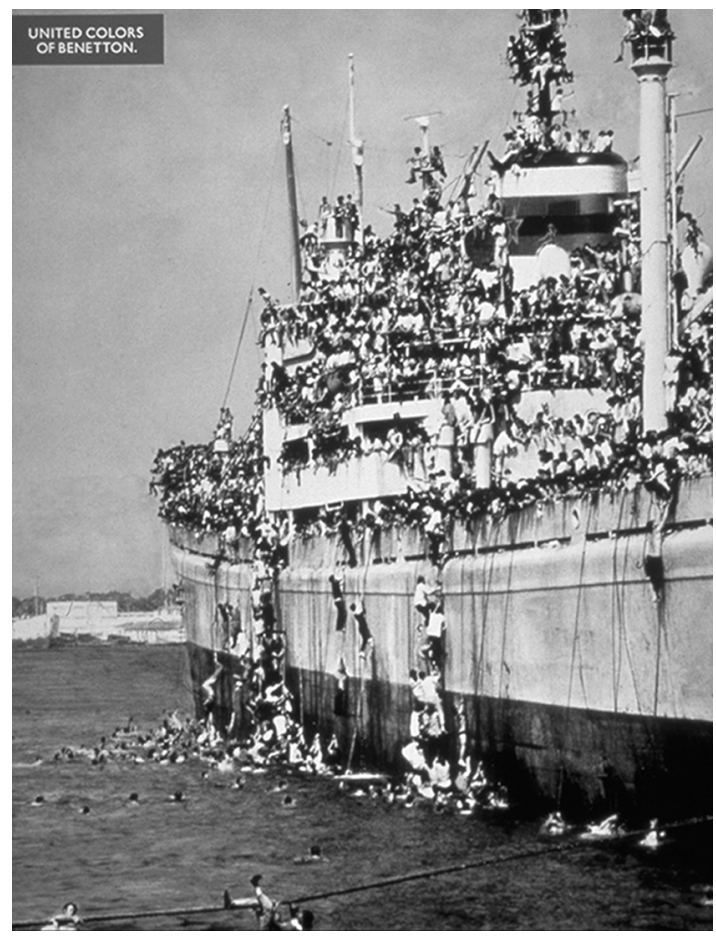

1 | Translation from the Italian by the author. A similar but shorter version of this article will be published in Drechsel, Benjamin/Leggewie, Claus, eds. 2010. United in Visual Diversity. Images and Counter-Images of Europe. Innsbruck: Studienverlag.

2 | In this article, the term "refugee" is used in a broader sense and not specifically to refer to persons whose asylum application have been accepted. 
The year after, Oliviero Toscani chose a photograph of a cramped vessel for his provocative Benetton campaign. ${ }^{3}$ Interestingly, not only Benetton but also right-wing parties referred to the image of the cramped boat. In the 9os, the German right-wing party Die Republikaner used a poster of a Noah's Ark overcrowded with immigrants and in 2002, Lega Nord used a similar motif for an anti-migration campaign. ${ }^{4}$ Today, boat people clambering ashore at Europe's borders are a frequent cliché in the European media, while most of the numerous victims dying at sea during the crossing remain invisible. It is usually the survivors that are depicted in the media, and not the dead or dying or the actual sinking of a boat. On the other hand, "successful" and therefore unobserved passages also go "undocumented".

The image of the full boat can vary: Noah's Ark could in fact have a positive connotation in a Christian context and a ship full of Albanian refugees waving upon arrival in Italy may transport another message, as is the case in the example mentioned above. ${ }^{5}$ Such pictures are often polyvalent, their sense can change according to the context, as they contain a multiplicity of possible meanings; the viewer can feel either pity or fearor both. Nevertheless, generally, packed ships have the potential to evoke a feeling of threat.

\section{INVASION}

However, the image of the "cramped boat" is not limited to the visual domain. During the Second World War, Eduard von Steiger, a member of the Swiss government, referred to Switzerland as a lifeboat in distress, with scarce supplies and restricted room. ${ }^{6}$ In claiming that there was a lack of space and resources, he wanted to legitimize a policy of highly restrictive admission of refugees to Switzerland. Many of the refugees who were refused entry later died in German extermination camps. Nevertheless, after the war, Switzerland imagined and presented itself as a humanitarian haven that had given protection to those who had needed it, as depicted in a huge two-part-poster made by Victor Surbek in 1946 .

This poster, portraying Switzerland and especially the Swiss army in a very heroic way, was used for an exhibit that was displayed in several Swiss cities just after the war.

3 | This picture was taken in August 1991 in the Albanian town of Durrës; see Pagenstecher 2008, p. 610. Pamela C. Scorzin mentions the same picture in her article in this publication.

4 | Pagenstecher 2008, p. 610 and http://www.leganord.org/ilmovimento/mani festi2002.asp (accessed March 05, 2010).

5 | http://www.corbisimages.com/Enlargement/Enlargement.aspx?id=TL017 003\&caller=search (accessed March 05, 2010).

6 | Häsler 1989, p. 180. 


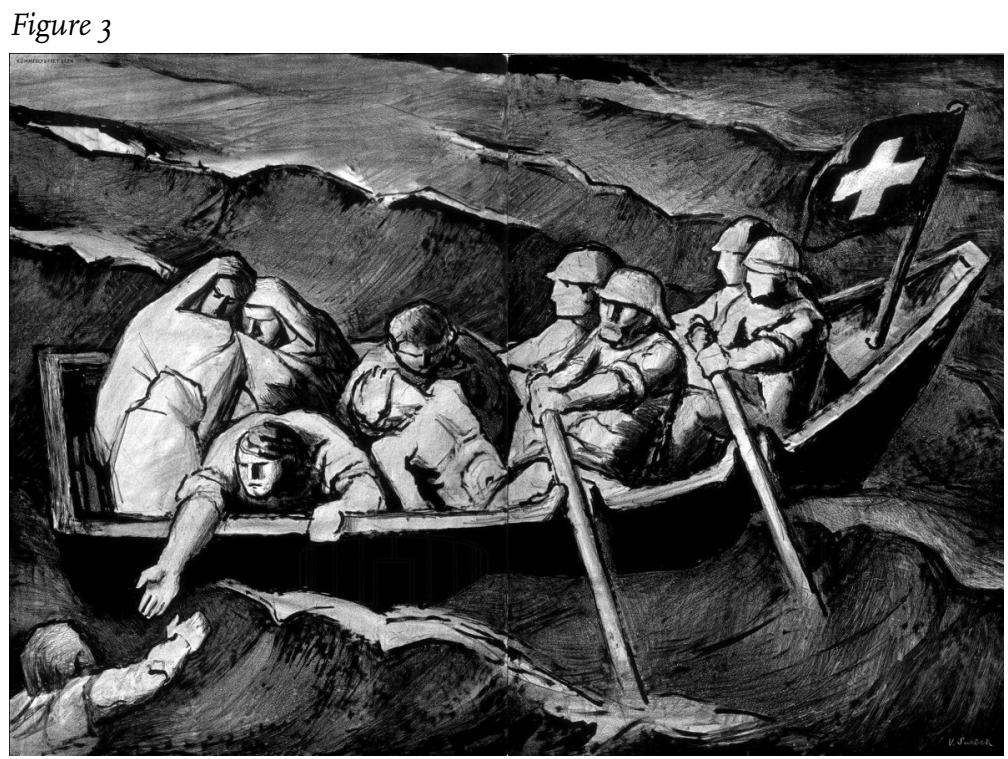

The aim of this poster was to collect money for the war-damaged countries of Europe. Even though Switzerland is shown here as an almost full lifeboat, there is still room for one more person, and therefore a strong man unhesitatingly reaches out to rescue a drowning man. In actual fact, during the war, Switzerland had for a long time granted asylum only to refugees who were under personal threat owing to their political activities, but not to those who were in danger because of their religion or ethnicity. More than twenty years later, in 1967 , Alfred Häsler initiated a critical discussion about Swiss refugee politics during the Second World War with his book "The Boat Is Full". Twelve years later, in 1979, the same author wrote an article about the refugees coming from Indochina.

Häsler urged Switzerland to accept more fugitives; the title of his article was: "Our Boat Is Not Full." It was in these days that the term boat people came into common use with the mass departure of Vietnamese refugees.

Today, cramped boats have become an icon of threatened borders. But the term icon as it is used here doesn't designate a particular photograph. In fact, similar pictures circulate widely. These images constitute a visual place of memory. However, that doesn't mean that these pictures are only effective on a visual level. In Byzantine times, icons were already characterized by an interrelation between the picture and the inscription. Furthermore, the boundary between words and images has fluctuated in the course of history. ${ }^{7}$ Moreover, icons do not possess a stable status: an icon is not for everyone and for all time an icon, and its meaning can change according to the context. ${ }^{8}$

7 | Foucault 1997.

8 | Perlmutter 1998, p. 10. 
Figure 4 and 5
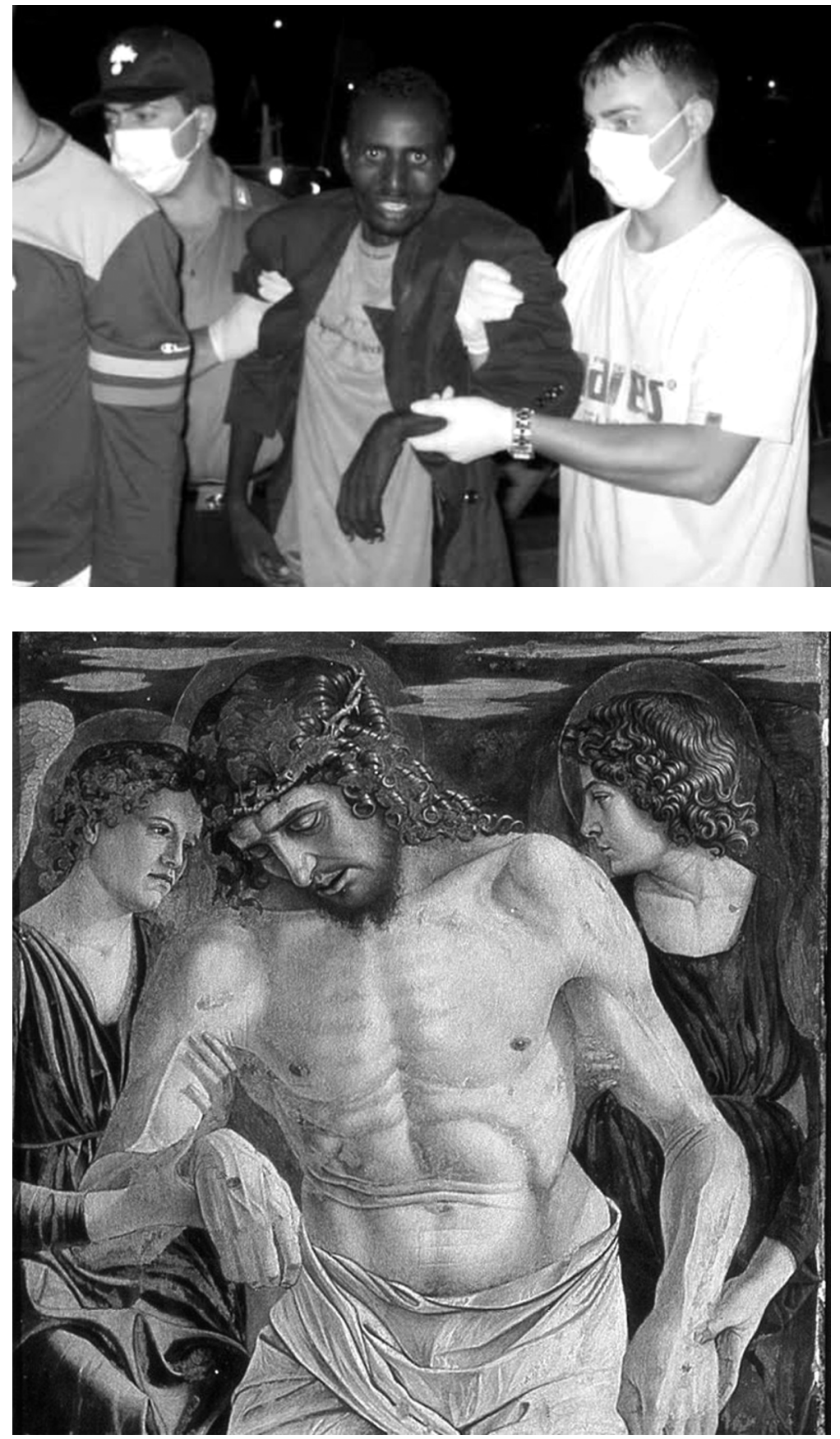

Bereitgestellt von | Universitaetsbibliothek Basel 


\section{INFECTION}

Strikingly, on photos of boat people arriving in Europe, the refugees are often received by persons wearing a mask. In these pictures, migration meets medicine-and the military. This is the case in a photograph by the European Pressphoto agency. The caption reads: "In the early hours of Monday 20 October 2003 Carabinieri assist a severely dehydrated and starving immigrant Somali man as he is brought to Lampedusa island harbour-an island midway between Tunisia and Sicily. Coastguards counted 13 dead bodies on the wooden vessel when it was spotted last night off the island."

The situation shown and described here clearly differs from the image of the cramped boat. We see a fragile individual, who arrived, as the caption says, in a wooden vessel and not in a big fishing cutter. Some of his fellow passengers have died on the way. The flabby arm and the drooping hand reveal the weakness of the Somali-a weakness that contrasts with the strong body of the man supporting him who is also wearing a white glove and mask. This composition recalls countless representations of the Pietà, for example the painting by Giovanni Bellini in the Basilica of St John and St Paul in Venice. ${ }^{9}$ On a polyptych of St Vincent Ferrer, a Spanish Dominican, Jesus is supported in a very similar way as the Somali refugee in the picture taken at the harbour of Lampedusa. An angel holds the bent arm of Jesus, so that the stigmata of Christ become visible. We can find the same posture, though as a reversed image, in the photograph of the Somali refugee.

Iconology always requires a certain amount of shared knowledge. I have no way of telling whether the photographer or someone at the European Pressphoto agency consciously had the image of the Pietà in mind when selecting this particular picture from a number of possible other ones. However, a visual tradition can cause a déjà vu effect ${ }^{10}$ and thereby influence the way a photo is perceived even unconsciously. ${ }^{11}$ The immigrant from Somalia thus appears here in visual imitation of the Pietà: as an innocent victim. Images of refugees in the tradition of Christian iconography are in fact widespread. For instance, you can find a motif recalling the Madonna with her child on the cover of Seyla Benhabib's book “The Right of Others" ${ }^{12}$ where the author argues for an ideal of porous borders. ${ }^{13}$ Or in the poster by Surbek, see especially how the upper part of one refugee's body is depicted in reference to Michelangelo's famous Pietà.

9 | This piece of art was created in 1460 , but the attribution is contested. However, for the point I am making here the question of authorship is immaterial.

10 | Leggewie 2000, p. 156.

11 | Assmann 1998, p. 30.

12 | Benhabib 2004.

13 | The photo recalling a Madonna was taken by Sebastian Bolesch in Afghanis$\tan$ in 2002. 
Photos are always taken from a specific perspective, and representations showing immigrants as victims are one-sided insofar as migrants are active agents, not merely passive victims without agency. ${ }^{14}$ They act in order to change their situation, even if the price is very high. There is however an important difference between the two pictures, the polyptych of St Vincent Ferrer and the Somali refugee, as the latter is alive, staring at us, thus breaking out of his role as a merely passive victim. At the same time, the picture of the Somali can provoke not only pity, but also fear, as the mask hints at the possibility of infection. This fear is born of the discursive and iconic connection between infection and immigration.

Medical discourses have long been important for the creation and legitimation of borders and for attempts to control the movement of people. Passports, for example, were to some extent a product of measures against the plague. My point here is not to downplay the medical risks that can result from the movement of people. But after taking a closer look at such pictures-for example, by analyzing the TV newscast-it becomes clear that very often only some of the persons present wear a mask, while others, performing the same tasks and standing just as close to the immigrants, do not. People's motives for wearing a mask are thus not at all evident. ${ }^{15}$ Furthermore, "can we really be certain that immigrants have so many more infectious diseases as to justify our fear of them, whereas business travelers, sex tourists, students, all the other millions who cross international borders every day are somehow less affected by them? SARS has taught us differently" ${ }^{16}$, as Philipp Sarasin has pointed out. This is why he emphasizes "how quickly fact and fiction melt in this area"17.

The mask has an iconic character, but its connotation can vary. For example, the mask became more common in Europe with the bird- and the swine-flue. The mask was for some time a very "popular" motif for the mass media: In July 2009, on the cover of the Swiss tabloid L'illustré for example, Roger Federer and two other celebrities were shown in a photomontage wearing a mask. ${ }^{18}$ In China, during the time of SARS, the wearing of a mask was an expression of solidarity. "The mask symbolized a rule of conduct-namely an obligation to protect the wider community-and an expectation regarding how one was to be treated by others [...]. More simply, the mask was the emblematic means by which people communicated their responsibilities to the social group of which they were members." ${ }^{\prime 19}$ Howev-

14 | See here Fassin 2001, p. 5 or Bleiker 2007, p. 149.

15 | I made this observation regarding the Spanish Telediario TVE in 2008, specifically on August 26 (15:23), September 2 (15:20), September 4 (15:10), September 14 (15:15), September 22 (15:22).

16 | Sarasin 2006, p. 220.

17 | Sarasin 2006, p. 217.

18 | http://www.illustre.ch/edition/2009-30/index.htm (accessed 03 March, 2010).

19 | Baehr 2008, p. 150. 
er, the significance of the mask is different in the analyzed pictures, which were obtained from European stock photo agencies. Here, territorial borders are superimposed on the boundaries of the body; migration appears at the same time as an assault upon the integrity of one's own body and that of Europe. Even though, in the constellations examined here, the image of the full boat and of the immigrant as a victim are connoted very differently, both pictures share a common feature: the fear of infection. Such images become part of our collective and cultural memory and thereby shape the perception of immigration as a threatening danger. However, it is remarkable that in Lampedusa tourists who are physically close to the site of conflict are usually shielded from its sight. Furthermore, the majority of the illegalized immigrants in Europe do not arrive as boat people; they come by land or by air. And in Europe, most of the so-called illegal immigrants have never crossed a border illegally, but rather had their residence permit withdrawn. ${ }^{20}$ Despite this fact, the European icon for "illegal immigration" seems to be condensed to cramped boats full of male Africans.

\section{Colonial connections}

A poster made by Lega Nord shows a face of a Native American with a big feather headdress. The caption reads: "They were subject to immigration, now they live in reservations." ${ }^{21}$ Under the logo of the Lega Nord showing the Lombard hero Alberto da Giussano with his sword, is written in red „Pensaci“, “Think about it“. Here, today's immigration is depicted as a colonial invasion. Following this logic, if immigration is seen as a colonial invasion, this needs to be answered by military means. But this suggested analogy between today's immigration and the colonial invasions is misleading, as there is no state with colonial ambitions behind today's immigrants to Italy who want to participate in the established economic system and not replace it by another. Quite the contrary, the European illegalization of immigration very often hurts people coming from former colonial regions, which becomes visible in the two photos discussed in this article: During Fascism, Albania was occupied by Italy and Somalia was an Italian colony, where the carabinieri were involved in atrocities. But these historical connections linking the past with the present are very often invisible in today's discussion about immigration. Even Switzerland, that was never a formal colonial power, participated in and profited by European Colonialism. In Swiss posters as well, migration is depicted as occupation and a kind of colonization.

20| Schwenken 2006, p. 13.

21 | Translation from the Italian by the author: "LORO HANNO SUBITO L'IMMIGRAZIONE. ORA VIVONO NELLE RISERVE!” http://www.leganord.org/ilmovimento/ manifesti2008.asp (accessed February 10, 2009). 
Figure 6 and 7
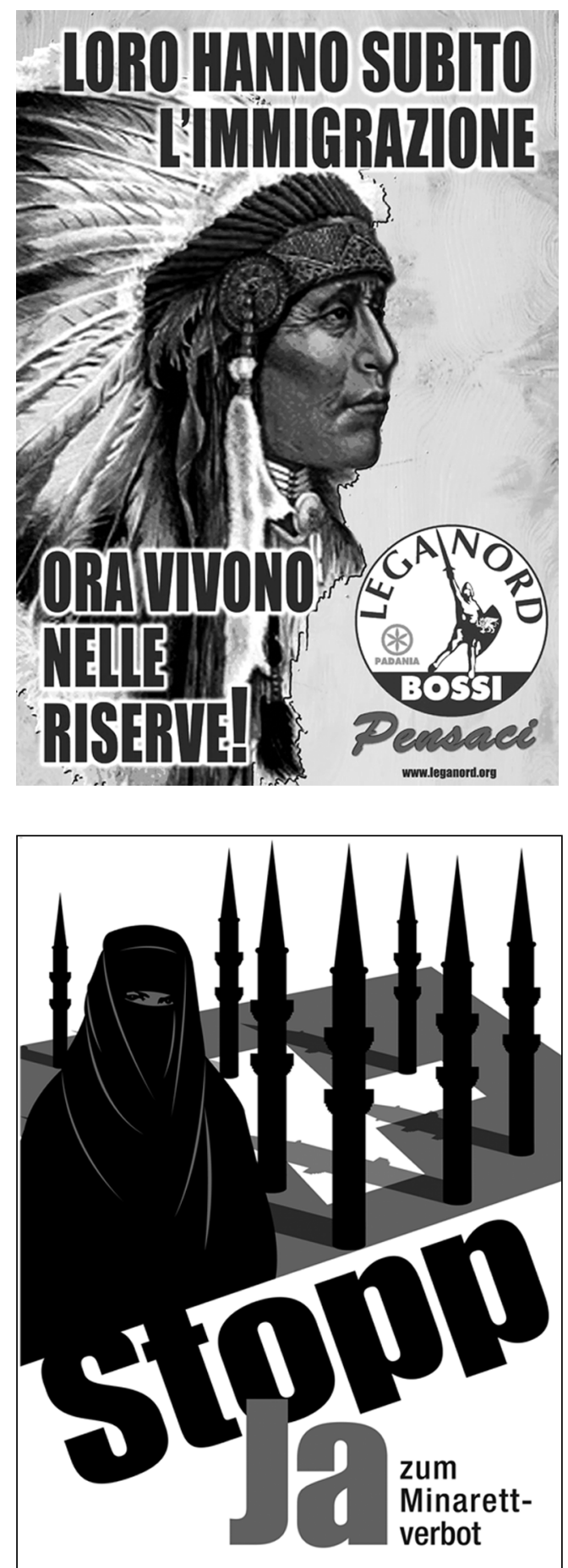

Bereitgestellt von | Universitaetsbibliothek Basel 
This is for example the case in a poster that was used for the initiative to ban the construction of new minarets. Here, the symbol of a certain group of migrants was illegalized (at the time of the vote, there were only four minarets in Switzerland). In the poster, we see a Swiss flag shaped like a map of the country and occupied by black minarets shooting out of it like missiles or big penises. In the foreground, a woman in black shrouded from head to foot appears in a paradoxical way as both a threatening and potential terrorist danger and as a victim that has to be saved. The topos of intervening for the sake of women was and is, as Gayatri Spivak's work has shown, often used to legitimize colonialism. ${ }^{22}$ The poster was backed by the Swiss People's Party, which in 2009 had the largest number of seats in the Swiss parliaments. Some cities like Basel, Lausanne and Fribourg banned the billboards, based on regulations forbidding campaigns with racist discriminatory contents. The Federal Commission against Racism denounced the posters, saying they "defame Switzerland's peaceful Muslim population, feed prejudice and portray the Muslim community as wanting to dominate Switzerland, oppress women and trample on fundamental rights" ${ }^{23}$. Supporters of the ban claimed that the minarets were a political symbol of domination. It is a characteristic of discriminatory discourse, that the "Other" is described as both profoundly backward as well as extremely powerful, as a small minority that poses a grave threat to the vast majority.

\section{IN/VISIBILITY}

As an economic actor, Switzerland was part of the colonial constellation. But colonial violence was less visible here than in those states that explicitly understood themselves as colonial powers. It is not only this colonial past which is very often invisible (not only in Switzerland), it is also the illegalized immigrants themselves.

Also not very visible are the detainees in the deportation camps. These places are usually located in the periphery, and pictures showing these institutions circulate very seldom in the Swiss media. In Basel, for example, this prison-like building is located at the very edge of the city and near the border to Germany. In Zurich, it is in the area of the airport and therefore not easily accessible either. It is remarkable that fishing cutters packed with immigrants are a popular motif in European news media, whereas deportation camps receive only marginal coverage; they do not get a lot of public attention, at least in Switzerland. But there is not only a strategy of invisibility at work here, but a complicated dialectic of visibility and invisibility: For the spectacle of deterrence, the camps have to be visible

\section{2 | Spivak 1988.}

23 | http://edition.cnn.com/2009/WORLD/europe/11/29/switzerland.minaret. referendum/index.html (last accessed May 07, 2010). 
for the sans-papiers themselves. ${ }^{24}$ Furthermore, the camps can signalize that something is done against "illegal immigration". For journalists, it is very difficult to meet the detainees, and the NGOs working in these places shouldn't be too visible in the media in order to be able to carry out their work. The detainees themselves can be perceived, in Gayatri Spivak's terms, as subalterns who do not have the position and possibility to have their voices heard in public. ${ }^{25}$ Sometimes, their "answer" to this situation is to set fire to their cells, as it happened several times here in Basel in 2007. The success in silencing illegalized immigrants here quite literally fanned the flames. Nevertheless, there are attempts to counteract this invisibility.

\section{Figure 8}

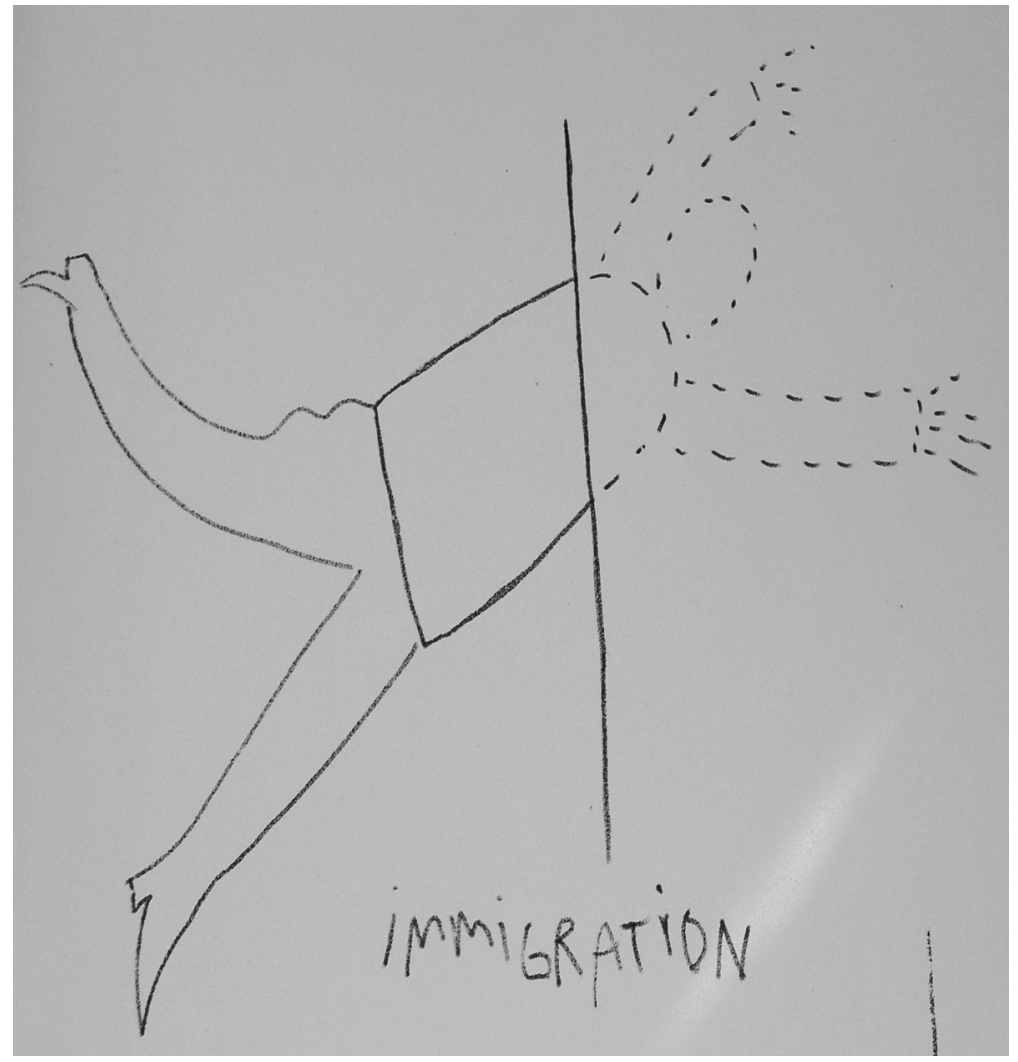

24 | I also investigate these problems in my dissertation Eine gestische Geschichte der Grenze. Wie der Liberalismus an der Grenze an seine Grenzen kommt, to be published in 2010 .

25 | Spivak 1988. 
On a white wall we see the black, sketchy silhouette of a falling person. The part of the body that breaks through a boundary is painted dashed; the fingers look like a skeletal hand. „I Am Not Exotic-I Am Exhausted“, says the title of this graffiti-like project which was displayed in a public space in Basel in 2007. It visualised the invisibility of illegalized immigrants. The artist creates a transitory and at the same time ongoing project, which manifests itself anew on each wall. His tools are cheap felt-tip pens. As this (for once not illegal) graffiti will be erased after a certain time, Dan Perjovschi eludes the usual criteria of the traditional art market, where a particular product generates a profit. Illegalized immigrants are also often accused of violating the standard rules of the market. ${ }^{26}$

Some months before, the Romanian artist Dan Perjovschi had used a similar figure for an exhibition in the Museum of Modern Art in New York. The situation Perjovschi wants to depict is similar in all these places, as the artist himself has stated. ${ }^{27}$ In Geneva in 2008 , a bronze statue by Senegalese sculptor Ousmane Sow was unveiled. It stands near the train station. The monument shows an oversized seated man dressed for winter, in a heavy overcoat and a cap with earflaps. The figure is reading a newspaper. The inscription of the monument reads: "In order to make their silence speak." 28

Incidentally, two years before, in 2006 , another Ousmane Sow, a refugee from Guinea, died of thirst in a Swiss prison as a result of his hunger strike in protest against a court decision. ${ }^{29} \mathrm{~A}$ study in 2005 estimated there were 90,000 unauthorized people living in Switzerland, other sources speak of 300,000 persons. ${ }^{30}$ Women mostly work in private households, while men are employed on construction sites and in agriculture. Geneva is estimated to have a sans-papier population of at least $10,000 .^{31}$ It may not be a coincidence though, that such a statue was first created in the French speaking part of Switzerland. It is this region that often takes a stand against the growing repression that illegalized immigrants today have to face, for example the city of Lausanne, which backed the right of children of illegal residents to pursue apprenticeship programs. Generally, policies are getting more and more restrictive in Switzerland for illegalized immigrants - as in other countries in Europe. But in a surprise vote, in March 2010, one house of the Swiss parliament supported the decision taken in Lausanne to give the right to pursue apprenticeships to children

26 | I discuss this (misleading) argument in my dissertation Falk 2010.

27 | Perjovschi 2008, p. 74.

28 | Translation from the French by the author.

29 | http://www.augenauf.ch/bulli/art/b048a07.php (accessed February 28, 2010).

30 | http://www.sans-papiers.ch/site/uploads/media/AA-Traber_AndreaFS_08.pdf (accessed March 01, 2010).

31 | http://www.geneva-city.ch/culture/coin_presse/dossier_presse/dp0us maneSow.pdf (accessed March 01, 2010). 
of undocumented immigrants. ${ }^{32}$ Some right-wing politicians reacted very harshly to this intention and labeled it as illegal. ${ }^{33}$

The statue in Geneva does not want to honour a famous person as in the artist's series "Merci", where, among others, statues of Gandhi, Rosa Park, or Mandela are being created, ${ }^{34}$ but commemorates the sanspapiers. The artist himself is an immigrant who moved to France while in his twenties. Ousmane Sow said his only directive from mayor Patrice Mugny, a member of the Green Party, was to create a figure of "dignity" paying tribute to immigrants without the required residence permit. The mayor wrote in the press release that the sculptor would inscribe the solidarity with victims of social injustice and minorities in the public space and thereby remember Geneva's vocation to be an open city. ${ }^{35}$ A group supporting illegalized immigrants welcomed the statue "Limmigré". But at the inauguration ceremony it hoisted banners saying: "A statue is fine, a statute (protecting sans-papiers) is better." 36

Also in France, the topic of the sans-papiers is highly contested. In the small city of Billère, the mayor Jean-Yves Lalanne, a member of the Socialist Party, inaugurated in 2009 a wall remembering deported illegalized immigrants who lived in this region before they were expelled from the country. In big letters words such as freedom, equality and solidarity, but also arbitrariness, deportation or shame are written on the wall of a public building. It recalls the "Communards' Wall" in Paris that commemorates the 147 communards that where shot here in 1871 . Two folded hands as in prayer (again a reference to Christian iconography), an airplane or the hexagon of France surrounded with arrows likes spines, are some of the depicted symbols. The name, age and profession of fifteen deportees are written in white on a black plaque. During the inauguration, the ceremony was disrupted by a dozen members of a party of rightist extremists. ${ }^{37}$ The préfet of the department, who represents the government and who exercises a control over local politics, also wants the wall to disappear. In January 2010 , the administrative court ruled that the fresco has to be erased. The mayor refuses to accept the illegalization of these mural images: He wants to bring the case before the European Court of Justice. And if, in the

32 | http://www.swisster.ch/news/society/swiss-parliament-sends-mixedimmigration-messages.html (accessed March 07, 2010).

33 | http://www.nzz.ch/nachrichten/schweiz/lausanne_probt_den_aufstand_ im_asylwesen_1.5056925.html (accessed March 07, 2010).

34 | http://www.ousmanesow.com/mac/fr/index.htm? mid=0\&sid=0 (accessed March 01, 2010).

35 | http://www.geneva-city.ch/culture/coin_presse/dossier_presse/dp OusmaneSow.pdf (accessed March 01, 2010).

36 | https://www.swisster.ch (accessed August 01, 2009).

37 | http://ceciestunexercice.wordpress.com/2009/11/06/un-mur-a-lamemoire-des-expulses/ (accessed March 07, 2010). 
end, there is no choice and the mural has to be erased, the mayor wants to paint the wall white. ${ }^{38}$

\section{Conclusion}

In my paper, I contrasted two types of pictures showing boat people in the European media. Either immigration is depicted here as an invasion, where refugees appear as an anonymous and threatening mass-or an individual refugee is portrayed as a victim, following the tradition of Christian iconography. Even though the analyzed image of the cramped boat and the image showing a victim are connoted differently, both pictures share a common feature: The fear of infection. Such images can evoke both pity and fear; they recall the concept of catharsis, where the catastrophe seems to be inevitable. This makes it easier for the beholder to refuse responsibility, all the more as it is not easy to determine who is to blame directly for this deadly drama which takes place in the Mediterranean.

Boat people are a frequent cliché in European media, even though in 2009 , such pictures were less often present, as the media space was occupied by the economic crisis and the swine-flue. Furthermore, due to treaties for example between Libya and Italy, boats have recently been more often forcibly prevented from leaving, with less media coverage as a result, since only the ones that make it to the European borders receive any attention. The global problem of an unjust economic system manifests itself at the border and becomes visible here, for example at the beaches of Lampedusa or in Ceuta, but it is not actually produced there.

The European illegalization of immigration very often hurts people coming from former colonial regions. These historical connections linking the past with the present are very often invisible in today's discussion about immigration. Slogans such as: "We are here because you were there" 39 , used in demonstrations of (illegalized) immigrants, try to counteract this. Also monuments are raised in order to make illegalized immigrants and the violence produced by their deportation visible in public. Such monuments not only want to remind, but also to warn and challenge; they are directed to the past as well as to the present and the future. It is precisely the metaphor of a fortress of Europe, which evokes the image of a clear-cut boundary between in- and outside, that makes the existence of illegal immigrants inside Europe invisible. Besides, the metaphor of the fortress has some implications: There is a religious connotation to

38 | http://www.Idh-toulon.net/spip.php?article3700 (accessed March 07, 2010).

39 | http://www.newamerica.net/publications/articles/2005/were_here_ because_you_were_there (accessed March 07, 2010). 
it. ${ }^{\circ}$ Furthermore, in war no one is allowed to leave a fortress, which is not the case for the Europeans themselves. In fact, there are different laws applying to the movement of people. But even though Europe may evoke, under a certain perspective, a fortress, it is a fortress with an entrance for servants. ${ }^{41}$ Europe's borders thus become filters that weaken the position of the illegalized immigrants, as it is very difficult for sans-papiers to stand up for their rights. ${ }^{42}$

The illegalization of migration is produced by a contingent legal system, but in the media it is often naturalized and migratory movements are shown as a natural disaster, where the mass of African immigrants appears as a tsunami that floods the dam erected by the European Union. What global and local conditions make people leave, is more often than not shown in the mainstream media. Furthermore, the boundary which separates legal residents from illegalized immigrants is most often not seen by people who are not directly affected by it. Borders which are not perceivable are all too often the most powerful ones and the most impenetrable. Moreover, media consumers seldom come across the nationally approved compulsory measures for which they are clearly politically accountable-such as in Switzerland detaining illegalized immigrants in prison-like deportation camps for up to two years. States are clearly accountable for the deportation camps on their national territory; here, there is doubtless some possibility for action. However, the "home-made" violence produced by illegalizing immigration does not become visible in the media. Apparently, the visibility of deportation camps is (still) embarrassing for the "general public", as closed borders are in contradiction with a "freedom of movement", which would be in fact a classical liberal notion. 43

\section{List OF Figures}

Figure 1: Luca Bruno, Carabiniere with Mask, March 18, 1997. Photograph: AP/Keystone.

Figure 2: Oliviero Toscani, Benetton Group Campaign 1992.

Figure 3: Victor Surbek, lithograph, 1946, 127/182 cm.

Figure 4: Franco Lannino, Carabinieri assist a severely dehydrated and starving immigrant Somali man, October 20, 2003. Photograph: EPA/ Keystone.

Figure 5: Giovanni Bellini, Polyptych of St Vincent Ferrer, $72 / 67 \mathrm{~cm}$, Basilica of St John and St Paul in Venice, 1465-68. Source: Olivari, Mariolina. 1990. Giovanni Bellini. Antella: Scala, p.28.

40 | As embodied by Luther's famous hymn Ein feste Burg ist unser Gott.

41 | Marischka 2006, p. 152.

42 | Schilliger 2008, p. 166.

43 | This is one topic of my thesis Falk 2010. 
Figure 6: A poster made by Lega Nord from 2008/2009: http://www. leganord.org/ilmovimento/manifesti20o8.asp (accessed March 07, 2010).

Figure 7: Poster used for the initiative to ban the construction of new minarets in Switzerland: http://www.minarette.ch/pdf/F4_Plakat.pdf (accessed March 07, 2010).

Figure 8: Dan Perjovschi, "I Am Not Exotic-I Am Exhausted", Basel 2007, photo taken by the author.

\section{BIBLIOGRAPHY}

Assmann, Aleida. 1998. "Frauenbilder im Männergedächtnis bei Pater, Proust und Joyce.” In Bildergedächtnis, Gedächtnisbilder, ed. Marion Strunk, p. 24-65. Zürich: Edition Howeg.

Baehr, Peter. 2008. "City under Siege: Authoritarian Toleration, Mask Culture, and the SARS Crisis in Hong Kong.” In Networked Disease. Emerging Infections in the Global City, ed. Harris Ali and Roger Keil, p. 138-151. Oxford: Blackwell Publishing Ltd.

Benhabib, Seyla. 2004. The Rights of Others. Aliens, Residents, and Citizens. Cambridge: University Press.

Bleiker, Roland/Kay, Amy. 2007. "Representing HIV/AIDS in Africa: Pluralist Photography and Local Empowerment.” International Migration Review 51: p. 139-163.

Falk, Francesca. "Eine gestische Geschichte der Grenze. Wie der Liberalismus an der Grenze an seine Grenzen kommt." To be published.

Fassin, Didier. 2001. "The biopolitics of otherness." Anthropology Today 17: p. 3-7.

Foucault, Michel. 1997. Dies ist keine Pfeife. München: Carl Hanser.

Häsler, Alfred Adolf/Dürrenmatt, Friedrich. 1989. Das Boot ist voll: Die Schweiz und die Flüchtlinge 1933-1945. Zürich: Diogenes.

Leggewie, Claus. 2000. Amerikas Welt: Die USA in unseren Köpfen. Hamburg: Hoffmann und Campe.

Marischka, Christoph/Pflüger, Tobias. 2006. "Das militarisierte Grenzregime der EU.” Widerspruch 26: p. 143-154.

Pagenstecher, Cord: “'Das Boot ist voll'. Schreckensvision des vereinten Deutschland.” In Das Jahrhundert der Bilder. 1949 bis heute, ed. Gerhard Paul, p. 6o6-613. Göttingen: Vandenhoeck \& Ruprecht.

Perlmutter, David D. 1998. Photojournalism and Foreign Policy: Icons of Outrage in International Crises. Westport, Connecticut: Praeger.

Sarasin, Philipp. 2006. Anthrax. Bioterror as Fact and Fantasy. Cambridge, Mass.: University Press.

Schilliger, Sarah. 2008. "Migration im Kontext der Globalisierung des Kapitals.” In Zukunft der Demokratie. Das postkapitalistische Projekt, ed. Beat Ringger and Willi Eberle, p. 155-187. Zürich: Rotpunktverlag. 
Schwenken, Helen. 2006. Rechtlos, aber nicht ohne Stimme. Politische Mobilisierungen um irreguläre Migration in die Europäische Union. Bielefeld: transcript.

Spivak, Gayatri. 1988. “Can the Subaltern speak?” In Marxism and the Interpretation of Culture, ed. Lawrence Grossberg and Cary Nelson, p. 271316. Chicago: University of Illinois Press. 
Bereitgestellt von | Universitaetsbibliothek Basel

Angemeldet

Heruntergeladen am | 18.09.18 17:06 